\title{
Hydrological and Geochemical Changes Related to Earthquakes - Examples: Three Great Earthquakes of the XX Century in the Southern Apennines (Italy)
}

\author{
Raimondo Pece ${ }^{1}$ and Giuseppe Tranfaglia ${ }^{2}$ \\ ${ }^{1}$ Dip. di Scienze della Terra, Università di Napoli Federico II, \\ Naples \\ 2Italian National Institute for Environmental Protection \\ and Research, Rome \\ Italy
}

\section{Introduction}

Moderate and strong $(M \geq 5)$ earthquakes that take place in active tectonic crustal structures as South Apennines Chain, generate temporary or permanent environmental changes (geophysical, geochemical, geomorphic, hydrogeological and structural coseismic features). The repeated occurrence of these features leaves a geological signature in the recent stratigraphy and topography of an area, unequivocally related to the intensity of the local seismicity.

Moreover, many anomalous behaviours of aquifers have been noticed before, during and after a seismic event: sudden increase/decrease of spring flows, changes of mountain streams (streamflow level and/or flow rate) and water table level in wells, and also increase of the emanation of deep gases.

The study of the geochemical and hydrodynamic characteristics of aquifers and of their changes is considered a valid contribution to the knowledge of the natural processes connected to earthquakes, mostly because the changes in the water-rock interaction are caused by the seismic stresses in the area where the tectonic deformation leads to the seismic event.

Hydrological anomalies concomitant and/or preceding seismic events has been widely known for at least 2000 years. Only in the last three decades such variations have been related to the characteristics of seismic sources. Also in Italy possible correlation between earthquakes and hydrological and geochemical anomalies have been recognised. Many other documents of the eighteenth and nineteenth centuries report information regarding variations of water levels and spring flows in occurrence with earthquakes.

Various interpretative models indicate how the fluctuations of water level in wells and the variations in the flow of springs and/or mountain rivers can be used as earthquake precursors and, moreover, to characterise the mechanisms of the seismic source, because they are significantly influenced by the deformation field associated to the earthquake. In particular, King and Muir-Wood (1993) proposed a model of the deformation associated to 
dislocation phenomena in complex systems of faults with different mechanisms and orientations. According to this model the coseismic dislocation during strong earthquakes produces a notable deformation of the superficial crust (surface layers) which influence directly the surface aquifers. Therefore, the hydrological regime and the spatial variation of anomalies are correlated to the spatial variation of the volumetric deformation produced by the phenomena of the coseismic dislocation in a wide area.

Here we resume the hydrological changes associated with some of the big earthquakes that occurred in the XX century in the Southern Apennines (Italy): 1930, 1980 and 1984. For the 23 July $1930\left(\mathrm{M}_{\mathrm{S}}=6.7\right)$ in Eastern Irpinia, 23 November $1980\left(\mathrm{M}_{\mathrm{S}}=6.9\right)$ in Irpinia-Lucania and 7 May $1984\left(M_{S}=5.8\right)$ in Southern Abruzzo earthquakes (figures 1a,b and 2a,b,c). We collected an abundance of well founded hydrological information, that cannot be ascribed to environmental or anthropical causes. We analysed also hydrometric and pluviometric data monitored from the hydrological network of Italian Hydrographic Survey (IHS), looking for significant changes in wells, springs and mountain streams. Hydrological data relative to wells, rivers and springs indicate that many changes can be correlated with the earthquakes. For these earthquakes, the pre- and co-seismic stresses and the tectonic deformations have been studied in order to find a possible model of interaction between stress state and hydrological anomalies.

In this chapter a description of Southern Apennines, the three earthquakes and the types of hydrological effects for each earthquake are reported.

\section{The southern Apennines}

The Apennines are a Neogene and Quaternary thrust and fold belt located in the hangingwall of the west-plunging Adria plate (Cinque et al., 1991; Doglioni et al., 1996). The Southern Apennines are a complex curved structure elongated from the Abruzzi-Molise to the Calabria-Basilicata border.

Several kilometers of vertical displacement occurred on the Tyrrhenian margin mainly along southwest-dipping normal and oblique slip faults. The extensional movements, due to their progressive shift toward the eastern sectors of the still uplifting Apennines, created deep tectonic basins elongated north-west.

\begin{tabular}{|l|l|l|l|l|l|l|}
\hline Year & Month & Day & Hour-Min & Epicentral Area & $\mathrm{I}_{0}$ & $\mathrm{M}$ \\
\hline 1688 & 6 & 5 & 15.3 & Sannio & XI & 6.7 \\
1694 & 9 & 8 & 11.4 & Irpinia-Basilicata & X-XI & 6.9 \\
1702 & 3 & 14 & 5 & Sannio-Irpinia & IX-X & 6.3 \\
1732 & 11 & 29 & 7.4 & Irpinia & X-XI & 6.6 \\
1805 & 7 & 26 & 21 & Molise & X & 6.6 \\
1930 & 7 & 23 & 0.08 & Irpinia & X & $\left(^{*}\right) 6.7$ \\
1962 & 8 & 21 & 18.19 & Irpinia & IX & $\left(^{*}\right) 6.2$ \\
1980 & 11 & 23 & 18.34 & Irpinia & X & $\left(^{*}\right) 6.9$ \\
1984 & 5 & 7 & 17.49 & Southern Abruzzo & VIII & $\left(^{*}\right) 5.8$ \\
\hline
\end{tabular}

Table 1. Major earthquakes in studied area. $\mathrm{I}_{0}$ epicentral intensity; $\mathrm{M}$ macroseismic magnitude according to CPTI04 (2004), $\left({ }^{*}\right)$ surface wave magnitude. 


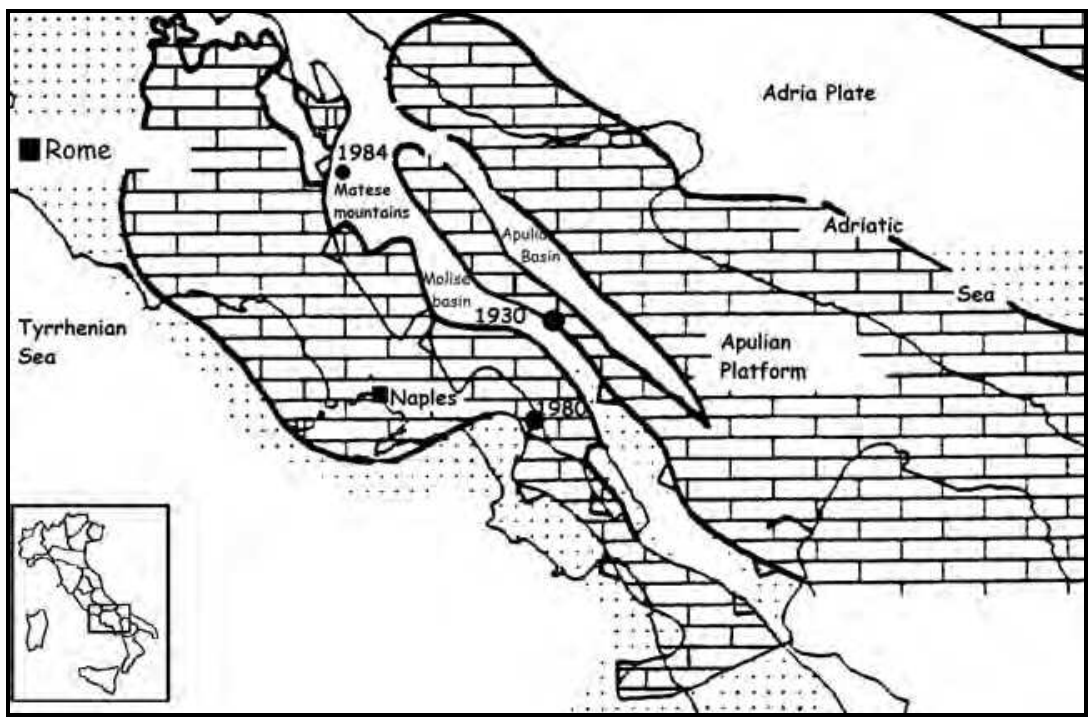

Fig. 1. (a) Sketch map of the Southern Apennines.

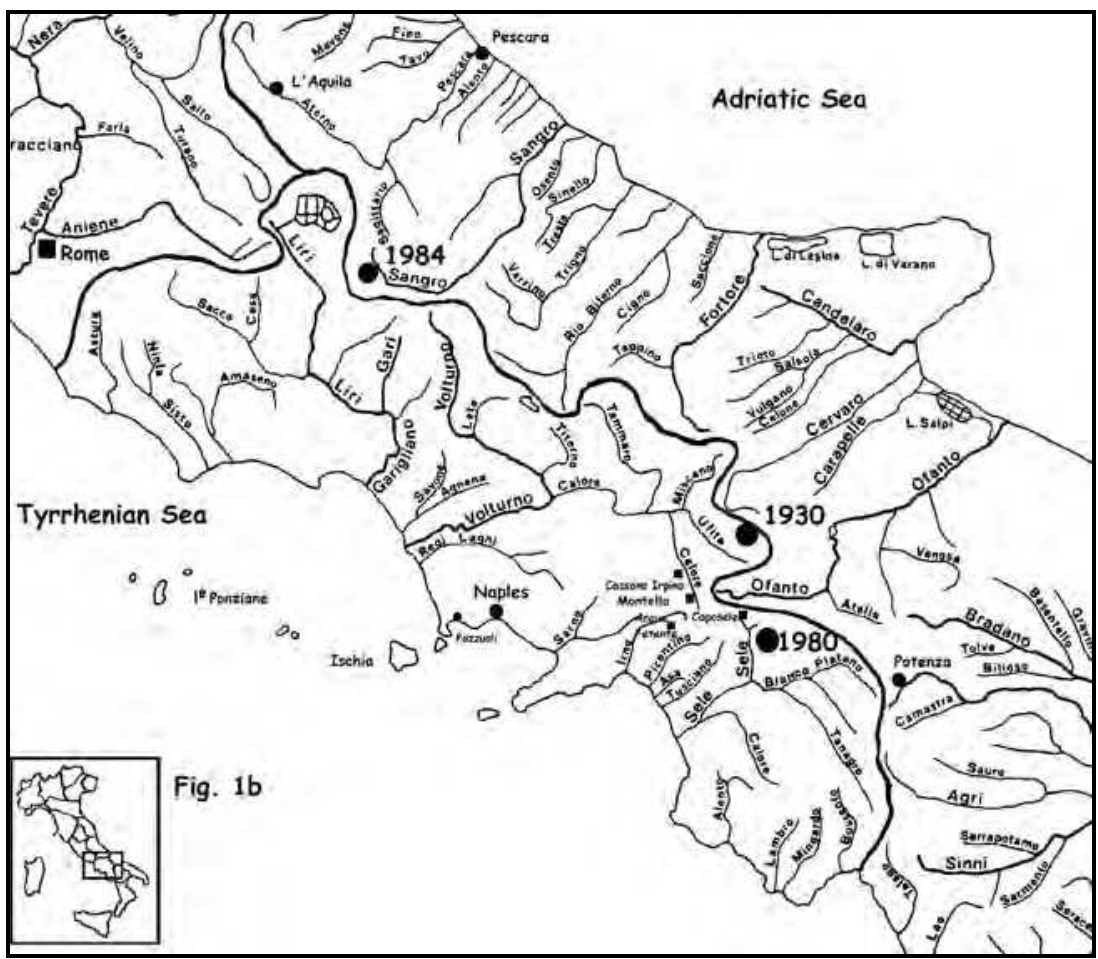

Fig. 1. (b) Hydrographic sketch map of the Southern Apennines with the epicenters of the three earthquakes 


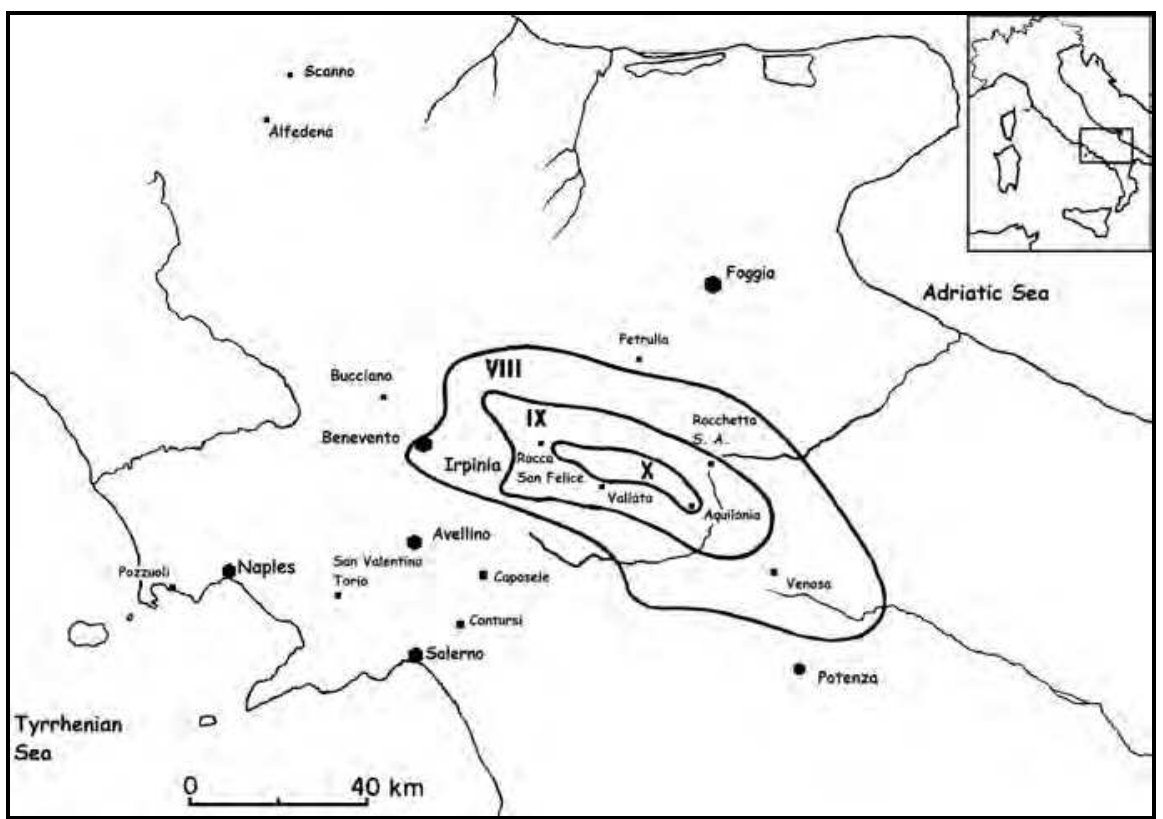

Fig. 2. (a) Isoseismal map for the 1930 earthquake

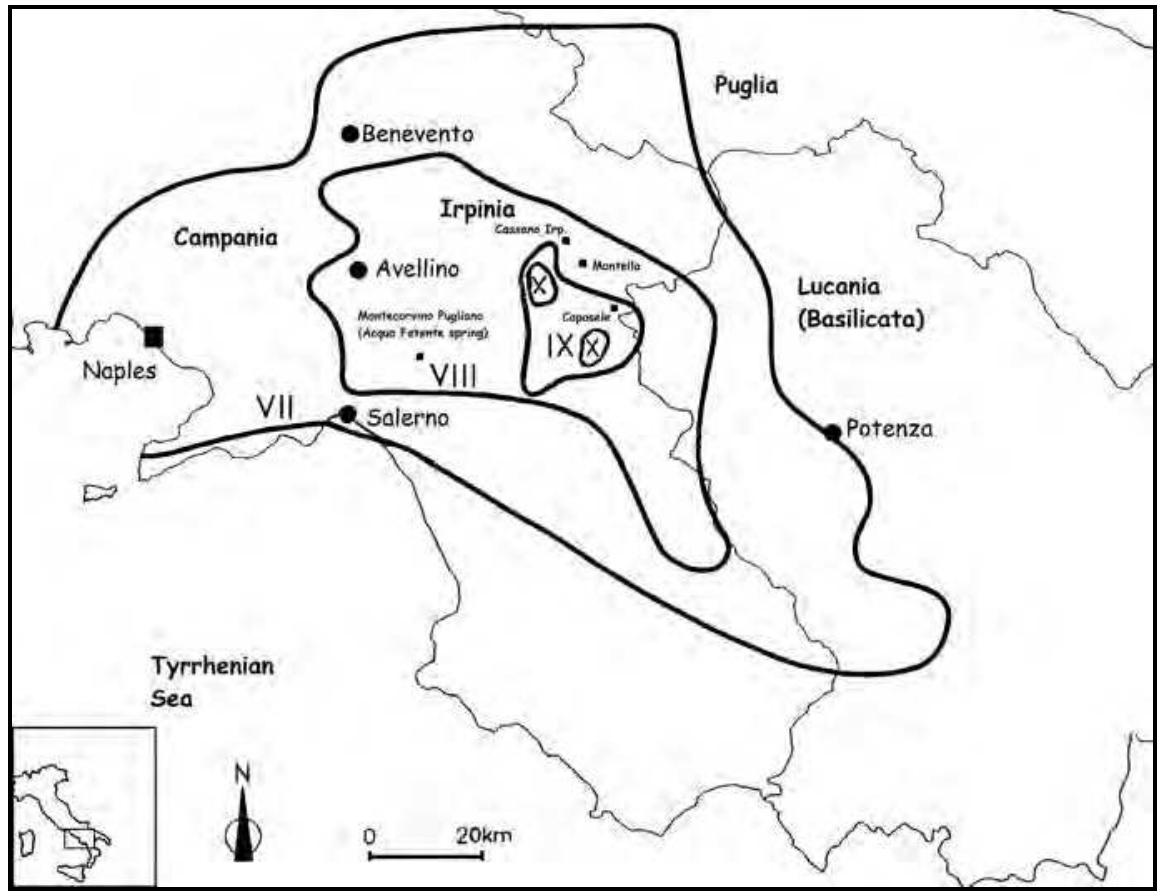

Fig. 2. (b) Isoseismal map for the 1980 earthquake 


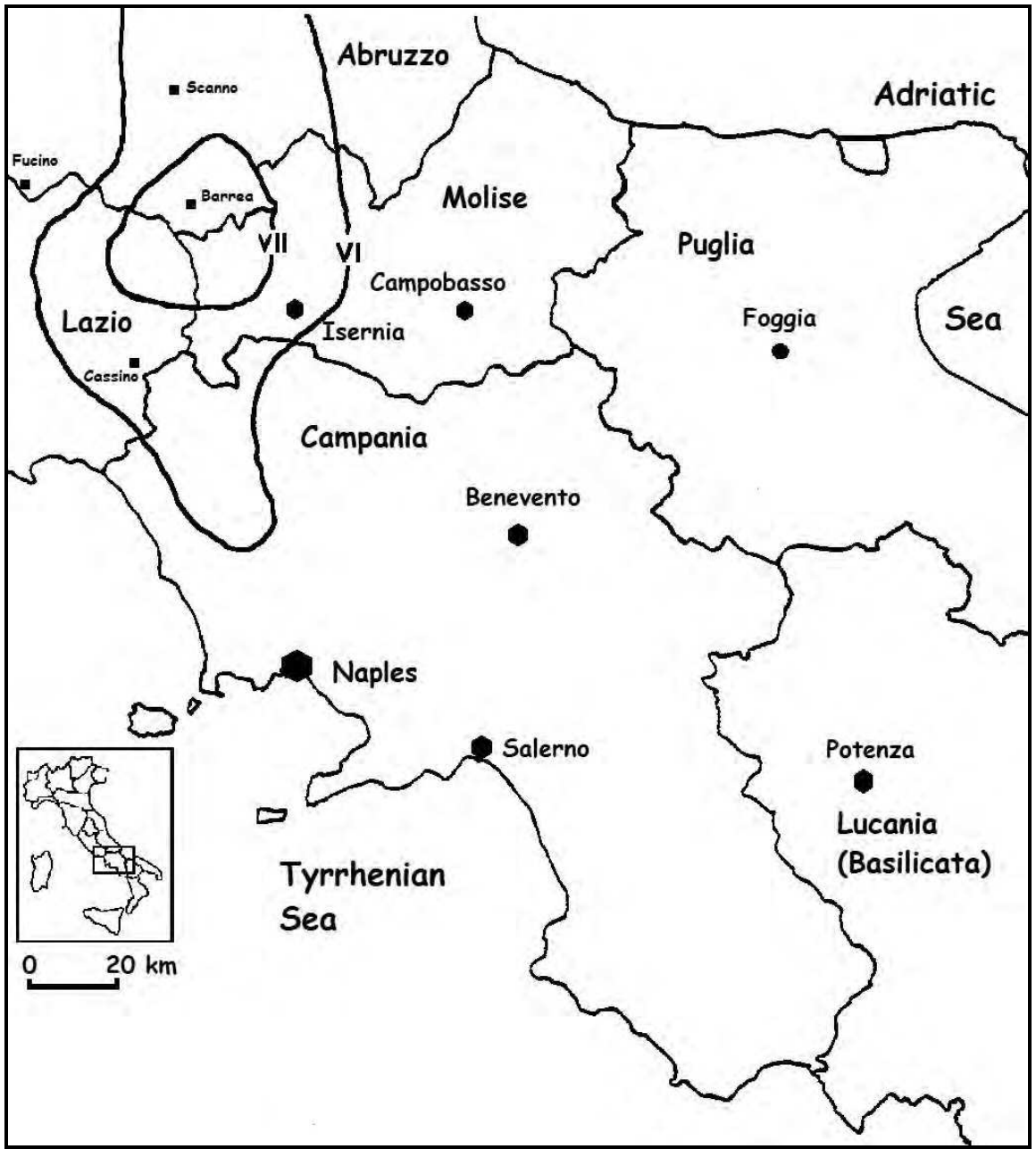

Fig. 2. (c) Isoseismal map for the 1984 earthquake

Studies of active tectonics and paleoseismicity confirm that extensional tectonics is still active in the southern Apennines, with slip-rates of several tens of millimetres per year, mostly for active faults from late Holocene until now (Westaway, 1992, 1993; Pantosti et al., 1993). The present-day tectonic setting of the mountain belt is governed by a system of Quaternary faults responsible for frequent moderate to strong crustal earthquakes, with typical hypocentral depths of 7-20 km. Table 1 lists the major earthquakes in the last centuries in studied area.

\section{The earthquake of July 1930}

The 23 July 1930 earthquake happened at 00:08 GMT with the greatest intensity of X MCS (Mercalli-Cancani-Sieberg scale) and a magnitude $\mathrm{M}_{\mathrm{S}}=6.7$, followed by many aftershocks, 
some of which with intensity of VII MCS. The epicentre of the main shock (figure 2a) was located at $41^{\circ} 05^{\prime} \mathrm{N}$ and $15^{\circ} 37^{\prime} \mathrm{E}$ in Irpinia (Freeman, 1930). The earthquake affected a very wide area, 36,000 km², comprising the regions of Campania, Puglia and Basilicata. The main shock was particularly destructive, resulting in 1425 fatalities, about 10,000 injured and more than 100,000 homeless people, 22 villages destroyed and about 40,000 dwellings damaged (Spadea et al., 1985). The epicentral zone of $\mathrm{I}_{\mathrm{MCS}}=X$ is elliptical and extends over an area of $180 \mathrm{~km}^{2}$ with the major axis of $34 \mathrm{~km}$ parallel to the Apennine trend (WNW-ESE). The area of the greatest effects, primary (surface faulting) and secondary effects (slope movements, ground cracks, hydrological anomalies) ( $\mathrm{I}_{\mathrm{MCS}} \geq$ VIII) is also elliptical, extending over about $6000 \mathrm{~km}^{2}$.

Many foreshocks and aftershocks accompanied the main event. At least two foreshocks preceded it at 23:30 on 22 July and at 00:30. The aftershocks with destructive effects occurred until 1931, also with intensity IMCS >VI (Spadea et al., 1985). Surface wave magnitudes (Ms) in the range 6.2-6.7 have been estimated for the 23 July 1930 earthquake. Whereas Westaway (1992) determined a seismic moment of Mo=3.2x1025 dyne-cm, Jimenez et al. (1989), on the basis of seismograms recorded at Jena (Germany), calculated Mo=2x1025 dyne-cm. The fault plane orientation was WNW-ESE (Apennine chain trend), the fault length was $32.6 \mathrm{~km}$ and the depth $15 \mathrm{~km}$, estimated on the basis of the equivalent ray of the major isoseismal lines (Gasperini et al., 1999).

Hydrological changes were observed in the whole macroseismic field, mostly in the far field, near the main carbonate aquifers in a widespread karstic environment (Esposito et al., 2009). They include flow increases both in springs and wells, turbid water and drying up of springs, appearance of new springs and variations in the chemical parameters of waters. From the data collected by the IHS (Annales 1925-1940) many anomalies were analysed by evaluating the shape and timing of hydrological changes in 151 sites both in the Tyrrhenian and in Adriatic watersheds (48 wells, 88 stream gauge stations, 15 springs). Spring flow at Madonna del Carmine increased from $10 \mathrm{l} / \mathrm{min}$ to $40 \mathrm{l} / \mathrm{min}$ after the earthquake, and at Monte della Guardia increased from 5 1/ min to 16 1/ min at the end of August (Esposito et al., 2009).

At Solfatara, a volcanic crater in Pozzuoli (near Neaples), at a distance of about $100 \mathrm{~km}$ from the epicentre, variations in endogenous activity were observed for about 20 days after the earthquake. Majo (1931) reports a temporary decrease in fumarolic gases, diffuse $\mathrm{H}_{2} \mathrm{~S}$ emanation from the soil, strong gas bubbling in a mud pool, and a notable temperature increase in monitored points. The possible influence of seismicity on gas release from depth can be demonstrated on the occasion of a small earthquake felt locally on 12 August 1930 near Pozzuoli. Table 2 reports the temperatures in ${ }^{\circ} \mathrm{C}$ measured in various sites inside the Solfatara crater (a) before 23 July, (b) during the period 28 July -8 August and (c) during the period 13 - 26 August. In a nearby site, at Stufe di Nerone, a considerable increase in $\mathrm{CO}_{2}$ and temperatures was also observed.

\begin{tabular}{|l|l|l|l|l|}
\hline \multicolumn{1}{|c|}{ Site } & \multicolumn{1}{c|}{ Town } & \multicolumn{1}{c|}{ a } & \multicolumn{1}{c|}{ b } & \multicolumn{1}{c|}{ c } \\
\hline Fangaia (mud pool) & Pozzuoli & 99.5 & 104.5 & 99.4 \\
Bocca Grande (main Fumarole) & Pozzuoli & 162.5 & 163.8 & 162.0 \\
Pietra Spaccata & Pozzuoli & 98.0 & 101.5 & 98.2 \\
Stufe di Nerone & Bacoli & 92.0 & 98.0 & 93.0 \\
\hline
\end{tabular}

Table 2. Temperatures in ${ }^{\circ} \mathrm{C}$ measured in various sites inside the Solfatara crater.

Another site with fumaroles and mud pools, Ansanto Valley, situated about $20 \mathrm{~km}$ from the epicenter, presented an increase in gas emission and mud boiling, together with light flashes (Alfano, 1931). This is a very sensitive site since such phenomena also occurred in this site for other earthquakes in the southern Apennines (Italiano et al., 2000). 
Near Venosa (the Vulture volcanic complex, not far from the epicentral zone) an increase in soil temperature was measured; Oddone (1932) imputed it to chemical reaction produced by a water table uplift in layers with Fe and S.

Effects on fumarole activity at distances of about $100 \mathrm{~km}$ from the epicenter seems hard to explain, but correlations between seismicity and volcanic phenomena are well known (Wakita et al., 1985; Hill et al., 2002; Husen et al., 2004).

Hill et al. (2002) pointed out that earthquakes and volcanoes are linked through plate tectonics and large earthquakes are capable of triggering eruptions within a matter of minutes or days at nearby volcanoes. In USA, a series of earthquakes as large as $M=6.3$ on 25-28 May 1980, caused turbidity and temporary increases in the discharge of hot springs in the Long Valley caldera of east-central California. These earthquakes had other obvious effects on the hydrothermal system, including emptying and refilling of boiling pools and temporary increases in fumarolic activity (Sorey and Clark, 1981). In central Japan anomalies in gas compositions were observed at fumaroles (at an epicentral distance of $9 \mathrm{~km}$ ) and three mineral springs (at epicentral distances of 50, 71 and $95 \mathrm{~km}$ ) about 1-3 months prior to an inland earthquake of $M=6.8$ on 14 September 1984 (Sugisaki and Sugiura, 1986).

Husen et al. (2004) report changes in geyser eruption behavior in Yellowstone National Park at very large distances (more than $3000 \mathrm{~km}$ from the epicenter) for Denali fault earthquake (Alaska), M=7.9. They interpreted these changes as being induced by dynamic stresses associated with the arrival of large-amplitude surface waves. They reported also an increase of seismic activity in Yellowstone Park and suggest that this seismicity were triggered by the redistribution of hydrothermal fluids and locally increased pore pressure.

It is plausible that such effects would occur in Southern Italy which is affected by young active tectonics with frequent strong earthquakes and many volcanically active areas (Pece et al., 1999).

Many anomalous behaviours of aquifers have been noted before, during and after a seismic event: sudden increases/decreases in spring flows, changes in piezometric levels in water wells, and increases in the emanation of deep gases (Gordon, 1970; Sorey and Clark, 1981; Whitehead et al., 1984; Wakita et al., 1985; Igarashi et al., 1992; Briggs, 1994; Curry et al., 1994; Rojstaczer and Wolf, 1992, 1994; Quilty and Roeloffs, 1997; Schuster and Murphy, 1996; Italiano et al., 2000; Thorson, 2001; Montgomery and Manga, 2003; Husen et al., 2004).

Characterizing the behaviour of aquifers and detecting anomalies in the late 1930s may be easier than in subsequent years since water resources were less exploited at that time. They are: pre- and co-seismic decreases in stream flows and water levels in wells; post-seismic increases in most of the discharges; only in some cases are they pre-seismic.

Here we illustrate the features of 7 types of the hydrological changes that we consider anomalous and connected with the 1930 earthquake. The first category of anomalous behaviour consists of decreases in stream flows before the earthquake, followed by increases after the seismic event. The four figures $3 a$ show the data collected daily at two stream gauges (located very near great springs) on the Tyrrhenian side and at two stream gauges on the Adriatic side. In the three figures $3 b$ the water levels measured with a 3-day frequency in one well in the Adriatic watershed and one on the Tyrrhenian side are reported, as well as the flow rate of Sanità Spring at Caposele (Sele river in figure 1b). In figure 3a.1 the anomaly consists of a sharp decrease in stream flow a few days before the seismic event, even if high rainfall preceded this decrease. The increase after the seismic event seems imputable to an anomalous discharge of the tributary springs that lasted for more than 10 days. In figure 3a.2, after the decreasing summertime trend, with a minimum reached on 24 July, there is a notable post-seismic increase from 25 July to 12 August due to 

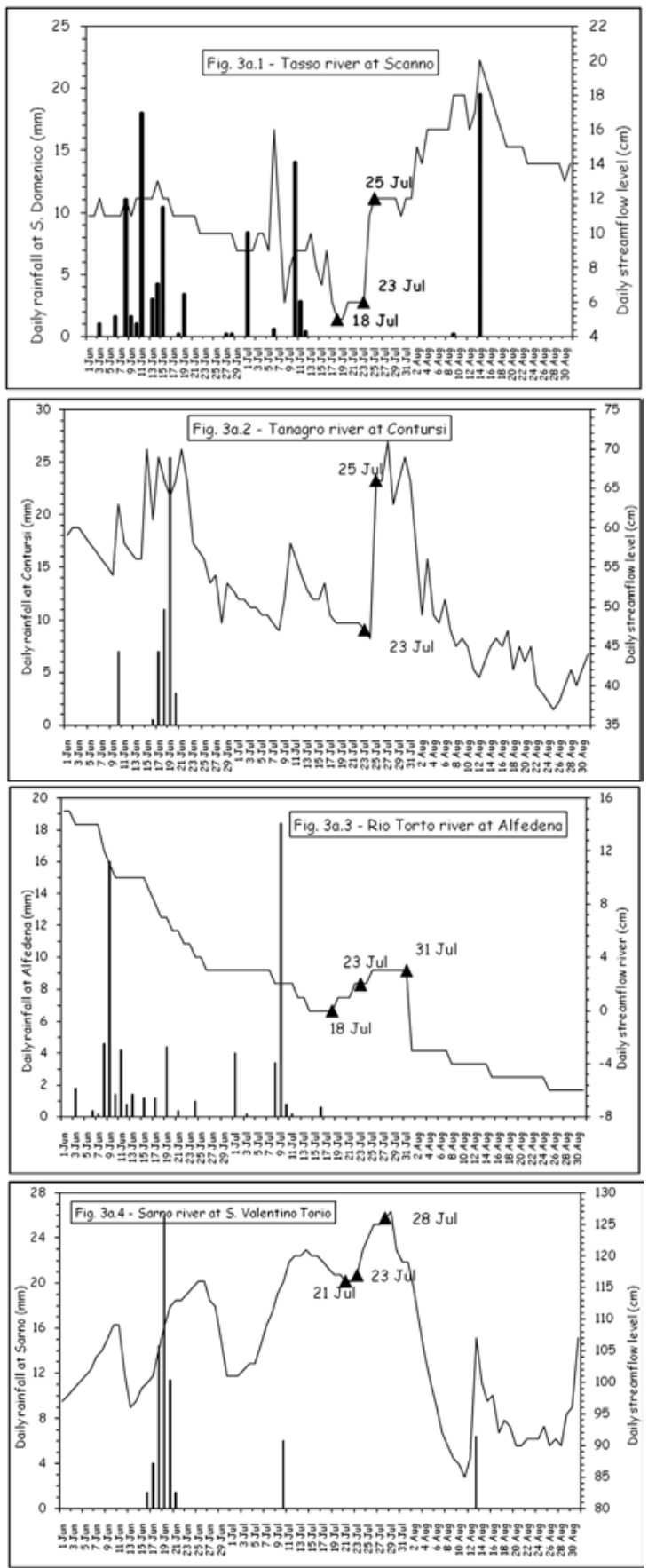

Fig. 3a.1 - 3a.2 - 3a.3 - 3a.4 (see text) 
contributions from numerous large springs. In figure $3 a .3$ the anomaly is a temporary increase of a few $\mathrm{cm}$ after the earthquake.

Of great interest is the post-earthquake behaviour of 3 springs that contribute to the Sarno river (figure 3a.4). The measurements carried out at San Valentino Torio, where the total contribution of the 3 springs is measured, indicate a stream flow increase with a maximum of $127 \mathrm{~cm}$ on 29 July (6 days after the earthquake) followed by a decrease to a minimum of $88 \mathrm{~cm}$ on 12 August, a minimum level never reached before.

These types of variations have been observed for many earthquakes all over the world. In the USA, Whitehead et al. (1984) observed many significant hydrologic changes after an earthquake on 28 October 1983 in Idaho $(M=7.3)$. Discharge measured at 10 springs and 48 stream gauging stations of the Big Lost River and surrounding watersheds increased in some instances by more than $100 \%$. The Loma Prieta earthquake (17 October 1989) with $\mathrm{Mw}=6.9$ produced hydrogeological effects reported by several authors who analysed the records of many gauging stations. Briggs (1994) analysed the hydrological effects of this earthquake in Waddell Creek watershed near Santa Cruz (California) at about $38 \mathrm{~km}$ from the epicenter. Numerous new springs appeared, and many inactive springs resumed flow; the springs maintained an exponential recession with minimal rain interference until they ceased flowing abruptly. As a consequence, post-seismic discharge near the mouth of Waddell Creek rose to 12.5 times the pre-earthquake discharge, followed by a gradual recession which was obscured by rain runoff beginning after about 50 days. Also Curry et al. (1994) observed very significant and unexplainable increases in the San Francisco peninsula and Santa Cruz Mountains watersheds immediately after the main shock of the Loma Prieta earthquake. For the watersheds of S. Lorenzo and Pescadero, Rojstaczer and Wolf (1992, 1994) observed that stream flows increased at most gauging stations within 15 minutes after the earthquake. Groundwater levels in the upland parts of watersheds were locally lowered by as much as $21 \mathrm{~m}$ within weeks to months after the earthquake.

As regard the 1930 earthquake, levels in water wells exhibited a general post-seismic increase. At Petrulla (figure 3b.1) and Bucciano (figure 3b.2) June and July rainfall did not influence the summer decreasing trend, and the increase lasted throughout August; note that at the Petrulla well the increase started 3 days before the earthquake. Figure 3b.3 shows the flow rate of Caposele spring at $22.5 \mathrm{~km}$ from the fault. A discharge increase of 150 liters/sec (about 3\%) was measured a few hours after the seismic event, compared to the measurement on 16 July 1930, a week before the earthquake (Celentani Ungaro, 1931).

Schuster and Murphy (1996) describe an analogous hydrogeological effect for the Draney Peak earthquake, $\mathrm{M}_{\mathrm{w}}=5.9$ in Idaho-Wyoming (USA), on 3 February 1994: a marked increase in groundwater flow (from 4,527 to 5,695 1/min) occurred at the spring for the Auburn Fish hatchery, $5 \mathrm{~km} \mathrm{NE}$ of the epicentre.

Also for the Idaho earthquake (28 october 1983, magnitude $=7.3$ ), Whitehead et al. (1984) analyzed water levels in 69 wells: those near the epicentre generally increased rapidly after the earthquake, by as much as 3 metres. Igarashi et al. (1992), for the 2 February 1992 Tokyo Bay earthquake $(M=5.9)$, reported possible precursor water level changes detected by the long-term groundwater observation sites. Three observation wells, about $90-110 \mathrm{~km}$ away from the hypocenter, showed anomalous changes: a rise and fall in water levels of $3-10 \mathrm{~cm}$ which began simultaneously 1-1.5 days before the earthquake. They excluded that rainfall or pumping could produce this change. The water level fall began to recover about 6 hours before the earthquake, followed by a coseismic rise of about $20 \mathrm{~cm}$.

In all figures 3 the rainfall is shown. Analysis of the yearly rainfall from 1925 to 1940 shows that 1930 had slightly less than average rainfall. Moreover, the epicentral area was less rainy than 
the mountainous part of the Apennines and watersheds on the Tyrrhenian side. The absence of rain on the days preceding and following the event shows that the increase in the level of the aquifer was totally due to variations in spring flow rates that flow down to the river-beds.

It is difficult to assess the anomalous variations (negative or positive). In some instances the stream flow data are sufficient to permit estimates of the total "excess" stream flow derived from a particular seismic event. Using the extensive USGS hydrological network it was estimated that the Hebgen Lake earthquake (17 August 1959; M=7.5) apparently produced about $0.3 \mathrm{~km}^{3}$ of water, the Borah Peak earthquake (28 October 1983; M=7.3) about $0.5 \mathrm{~km}^{3}$
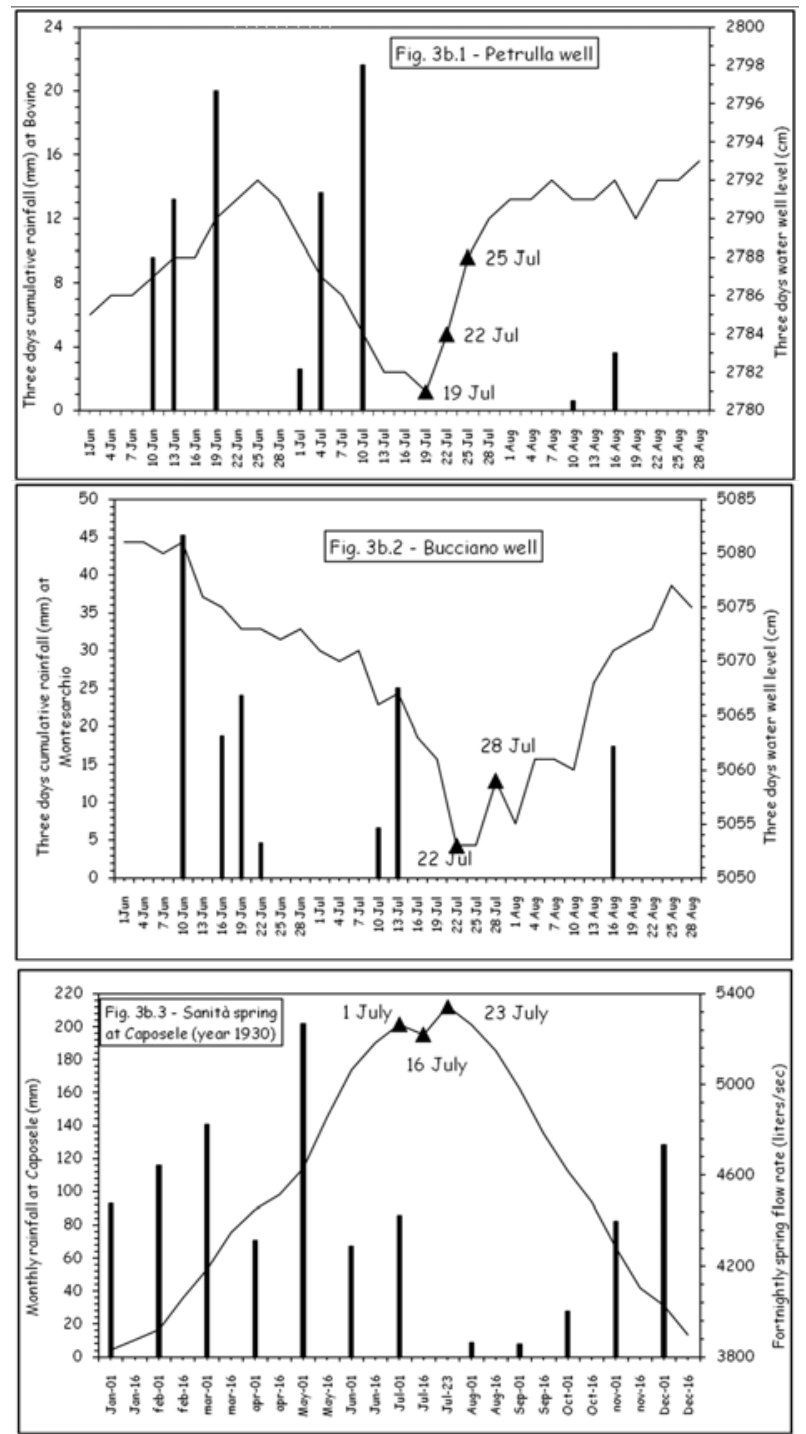

Fig. $3 b .1-3 b .2-3 b .3$ (see text) 
of water, and the Loma Prieta earthquake (17 October 1989; Mw $=6.9)$ only about $0.01 \mathrm{~km}^{3}$ of water (King and Muir-Wood, 1993; Rojstaczer and Wolf, 1994).

We performed an evaluation of the stage-discharge rating curves for 11 streams for which sufficient data were available (table 3). By assuming that the daily values collected in 1930 were constant in the 24 hour time frame, we calculated the average discharge in the entire anomalous period (Qav) and, obviously, the total discharge (Qtot) in this period. This permits a rough quantification of excess discharge (about $0.035 \mathrm{~km}^{3}$ for these 11 streams) which does not appear to be correlated with the distance from the epicentre.

Gordon (1970), following the Meckering earthquake (western Australia) of 14 October 1968 (mainshock $\mathrm{M}_{\mathrm{l}}=6.9$ ), reported an increase (of about $11 \mathrm{~cm}$ ) in water level in three boreholes $110 \mathrm{~km}$ west of the epicentre, which started 90 minutes prior to earthquake motion and

\begin{tabular}{|l|l|l|l|l|}
\hline \multicolumn{1}{|c|}{ Site } & $\begin{array}{c}\text { Anomalous period } \\
\text { (days) }\end{array}$ & $\begin{array}{c}\text { Qav } \\
\left(\mathrm{m}^{3} / \mathrm{d}\right)\end{array}$ & $\begin{array}{c}\text { Q tot } \\
\left(\mathrm{m}^{3}\right)\end{array}$ & $\begin{array}{c}\text { Epicentral } \\
\text { distance }(\mathrm{km})\end{array}$ \\
\hline $\begin{array}{l}\text { Aterno river at Molina } \\
\text { Tasso river at Scanno }\end{array}$ & 12 & 162174 & 1946084 & 179.0 \\
Sagittario river at Capo Canale & 28 & 62610 & 1565255 & 154.0 \\
Pescara river at Maraone & 6 & 317486 & 1269946 & 167.5 \\
Lavino river at Scafa & 93 & 1498499 & 13486494 & 200.0 \\
Zittola river at Montenero & 25 & 74608 & 1715990 & 175.0 \\
Rio Torto river at Alfedena & 15 & 9480 & 236995 & 129.0 \\
Trigno river at Trivento & 13 & 50574 & 758614 & 107.5 \\
Biferno river at Guardialfiera & 18 & 134317 & 1746116 & 107.0 \\
Fortore river at Stretta di Occhito & 11 & 536461 & 9656293 & 96.0 \\
Ofanto river at Rocchetta S. Antonio & 8 & 202098 & 2223075 & 70.0 \\
\hline
\end{tabular}

Table 3. Excess discharge of the 23 July 1930 earthquake. Qav and Qtot are, respectively, the average and the total discharge in the entire anomalous period.

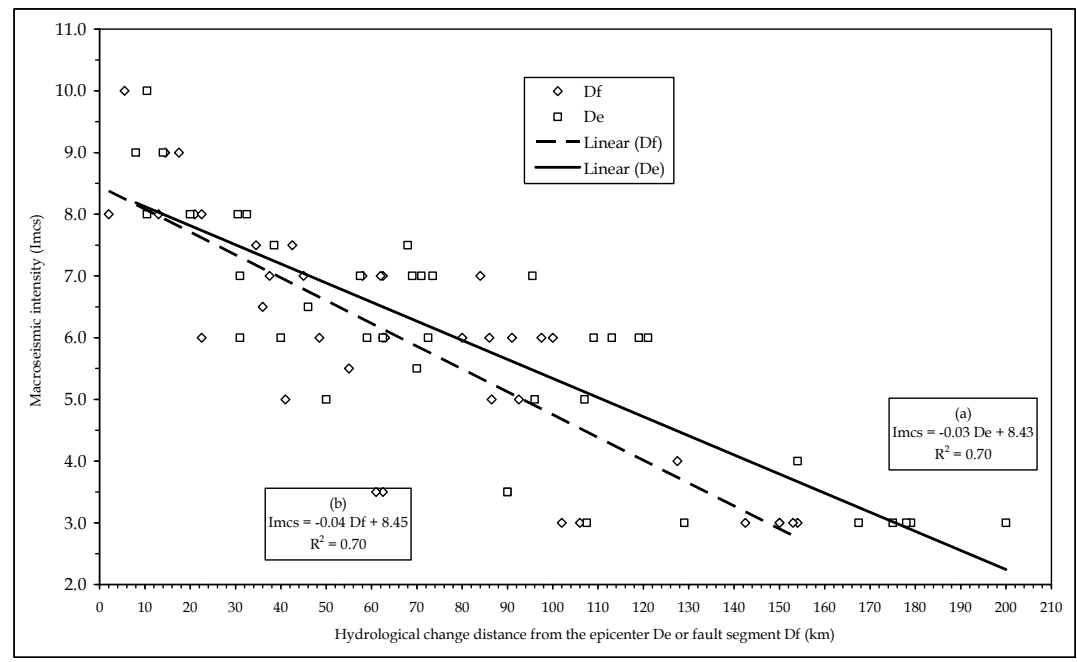

Fig. 4. Distance to epicentre (a) and to fault segment (b) versus intensity ( $\mathrm{I}_{\mathrm{MCS}}$ ). A clear negative linear regression is visible. 
lasted about six hours. For the 18 November 1755 Cape Anne historic earthquake in New England (USA) with an epicentral intensity MM=VIII, Thorson (2001) reported hydrological responses up to $275 \mathrm{~km}$ from the epicentre, consisting in coseismic, abrupt, long-term changes in the flow rate and chemistry of water wells from five towns in Connecticut.

The anomalies were evaluated to determine whether there were patterns of hydrologic change related to epicentral or fault distance. Figure 4 shows that: (a) most of the phenomena lie between $30-120 \mathrm{~km}$ from the epicentre, whereas the maximum distance was $200 \mathrm{~km}$; (b) most hydrological changes occurred within 30-110 km from the fault rupture segment. The maximum distance of such variations from the fault rupture was $155 \mathrm{~km}$. Note that few hydrological anomalies occurred near the fault or near the epicentre $(<30 \mathrm{~km})$.

\section{The earthquake of November 1980}

The 23 November 1980 earthquake happened inside a seismically active band extending from southern Abruzzo to Lucania (Basilicata). This Irpinia-Lucania seismogenetic zone is characterised by a complex seismotectonic structure, buried under the thick alloctonous terrains that constitute the Apennine Chain.

On the basis of geological, structural and geophysical evidences, the seismogenetic band has been subdivided in more seismogenetic zones characterised by a frequent seismicity, both historical as the earthquakes in 1561, 1694, 1851, 1857, 1930 with $\mathrm{I} \geq \mathrm{IX}$ MCS and recent, main shock-aftershock type, as the earthquakes in 1980, 1990, 1991 with $\mathrm{I} \geq \mathrm{VIII}$ and $5 \leq \mathrm{M} \leq 6.9$.

About 800 villages were damaged in Campania and Lucania. The Imax was X MSK. This great intensity and the nature of the geological structures caused very numerous effects. Surface fractures were observed in all the area from the epicentre till to the VIII isoseismal line. About 200 landslide phenomena were observed in an area more than $20.000 \mathrm{Km}^{2}$ wide around the epicentre.

The study of the hydrological effects has been carried out on measurements of water levels, spring flows measured each day, streamflow levels measured each day, continuous registration of water level in rivers (Esposito et al., 2001)

We considered also many other similar, but less continuous, measurements carried out during 1975-1985 (periodicity varied from weekly to monthly) on springs and rivers which exhibited a clear anomaly. Most of them are in the high Sele river and on Matese mountains (figures 5a-f).

Before the earthquake the trends of hydrometric levels were normal or decreasing, but show a general increase starting from 24 November, lasting for about 24-48 hours. In some cases the positive anomaly lasted till to 27 November.

A detailed study of the spring flow at Caposele and Cassano Irpino, located near the epicentre, have been carried out, by considering the monthly averages in 10 years (Pece et al., 1999). The year 1980 appears to be hydrologically anomalous.

In Fig. 5a the anomaly consists of the great increase in the flow rate of a thermal spring (Acqua Fetente) between 17 and 30 November (earthquake was on 23 November) and this increase lasted many months. All this behaviour is anomalous and the rainfalls could not produce such a sudden and great increase. It is sufficient to observe what is the contribution of each rainfall event on hydrograph of the flow rate. We suppose that the pre- and coseismic stresses modified the groundwater circulation.

In Fig. $5 b$ there is another type of anomaly. Measurements are carried out on the mountain stream by a river gauge and the continuous record shows that a decrease is followed by an 
increase recorded at 12:00 MLT each day. It is not possible that this increase is due to some rainfall (no rainfalls are present in 23 and 24 November). The response of water level to rainfalls in this site is almost contemporaneous, because the catchment area of rainfall is small (see 27 November). So the increase between 23 and 24 November appears to be imputable only to the seismic event.
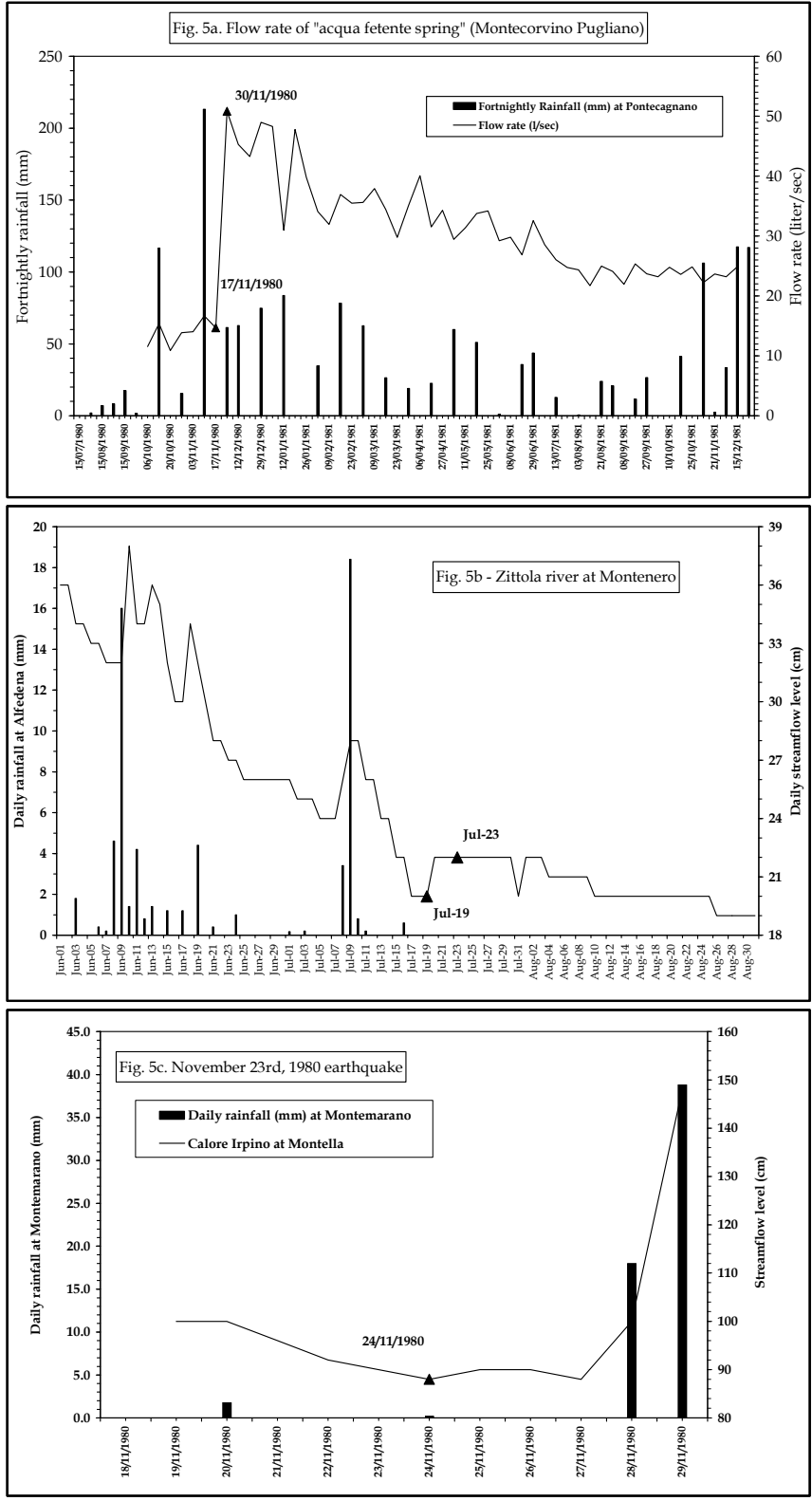

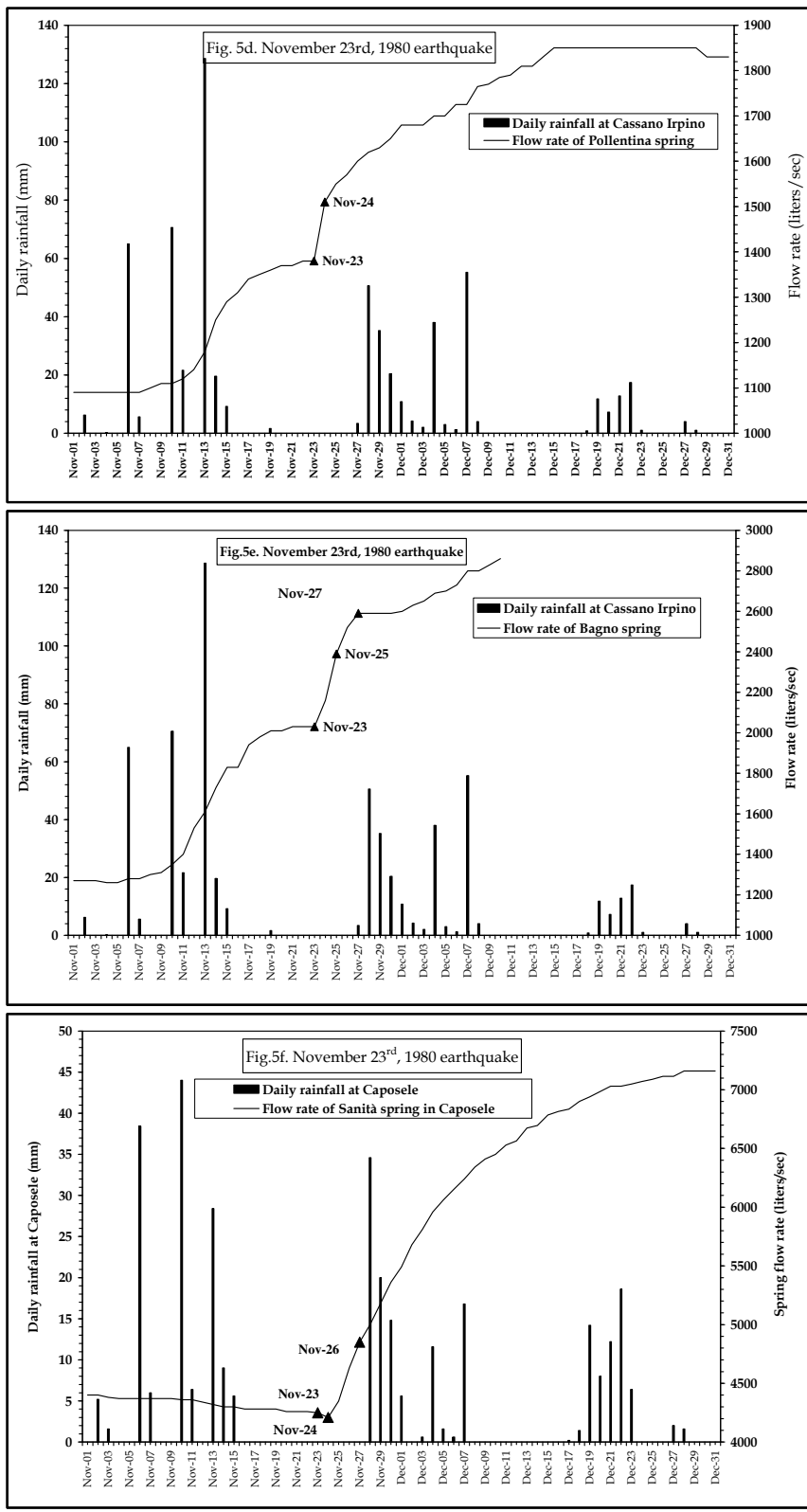

Fig. 5. Acqua Fetente spring (a); Zittola river at Montenero (b); Streamflow level of Calore Irpino at Montella (c); Cassano Irpino springs: Pollentina (d) and Bagno (e); Sanità spring at Caposele (f).

In Fig. 5c the anomaly seems to be the opposite of that shown in Fig. 5b. In fact, there is a decrease from 23 to 24 November: the increase took place on 25-26 November. Also in this 
case, no rainfalls occurred in those days. The decrease at this site can be explained by taking into account that near Caposele Spring the same behaviour is exhibited.

Figures $5 \mathrm{~d}$ and $5 \mathrm{e}$ show the hydrological anomalies consisting of the strong increase in flow rate of Pollentina and Bagno Springs, very near each other at Cassano Irpino. It seems that this increase started about ten days before the seismic event. A further sharp increase took place soon after the earthquake.

We retain that these increases cannot be imputable to the rainfalls that preceded the seismic event. In fact, Fig. 6 shows the trends of monthly cumulated flow rates of these two springs compared to the rainfalls in the decade 1975-1985. This figure also reports the flow rate of the Caposele Spring. The lag among rainfalls and increases in the flow rates is consistent: some months, with Caposele preceding Cassano Irpino.

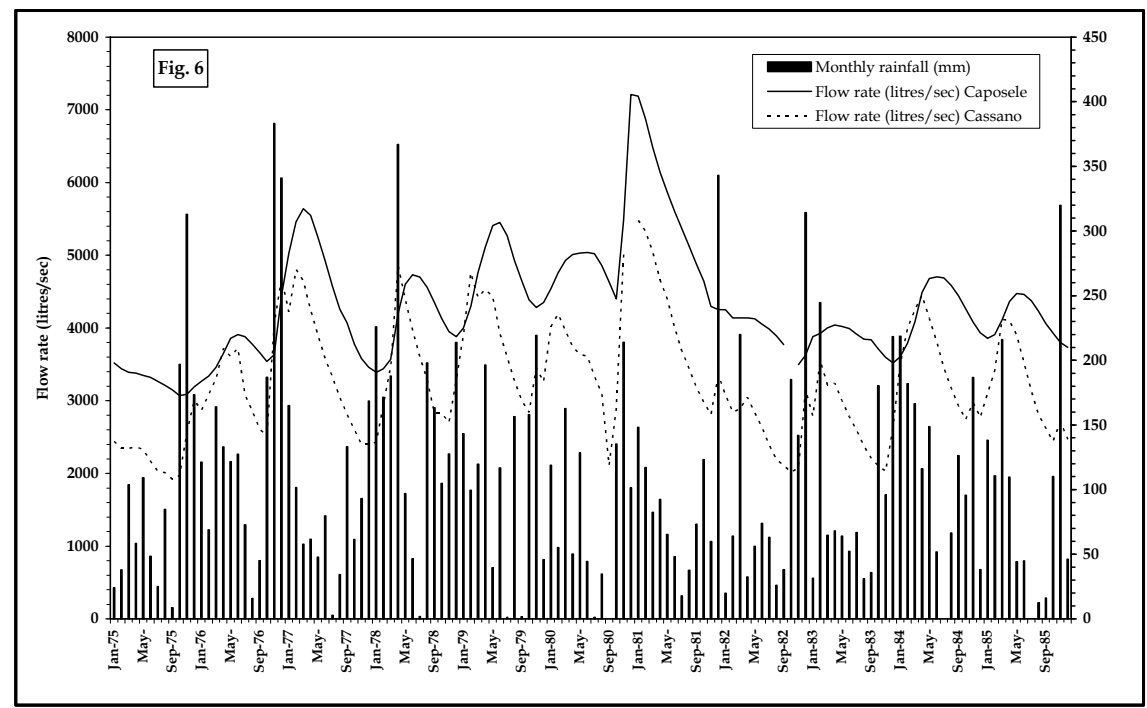

Fig. 6. (see text)

\section{The earthquakes of May 1984}

The seismic sequence which started in May 1984 consists of two main shocks, in 7 May $\left(\mathrm{M}_{\mathrm{s}}=5.8\right.$ seismic moment is $\mathrm{M}_{0}=0.59 \times 10^{18} \mathrm{Nm}$ and depth $\left.10 \mathrm{~km}\right)$ and in 11 May $\left(\mathrm{M}_{\mathrm{s}}=5.2 ; \mathrm{M}_{0}\right.$ $=0.21 \times 10^{18} \mathrm{Nm}$, depth $10 \mathrm{~km}$ ). The main shock fault plane was part of the Sangro fault, one of three major SW-dipping normal faults that take up much of the extension of this part of central Italy in Lazio and Abruzzo (figure 1a) (Westaway et al., 1989).

In order to evaluate the hydrological effects produced by the seismic sequence, we analyzed the data registered in 15 hydrometrical stations and the variations of levels of two lakes (Barrea and Scanno), all localised in the epicentral area and monitored by the Italian Hydrographic Survey.

Hydrological variations have been registered in 12 hydrometric sections. Among them, 3 hydrometric stations WSW in the epicentral area, and another station located west of the continuation toward north of the Val di Sangro fault did not show notable hydrological 
anomalies in the days before the event of 7 May, while during all this month flow rates were comparable with the average values calculated for the period 1979-89, even if the rainfalls from January to May 1984 have been lightly higher than the average.

Nevertheless, gas outpouring and water muddying have been noticed in the evening of 5 May, in the springs at Posta Fibreno, localized about $2 \mathrm{~km}$ before the hydrometric sections.

Also in the hydrometric section of Sangro river at Ateleta, the hydrological anomaly was pointed out only in the value of the average streamflow level in May 1984. Consequently, for this earthquakes we have a total of 14 sites where hydrological effects have been noticed, taking into account that in 3 sites (the Rapido and Gari rivers at Cassino, the Gari river at S. Angelo in Theodice) the positive hydrological anomalies preceded the earthquake of 7 May.

Figures $7 \mathrm{a}$ and $7 \mathrm{~b}$ show the anomalous behaviour in two studied sites. In Fig. 7a we show an hydrological anomaly consisting of a strong increase in the streamflow rate of the Sangro River at Barrea, not imputable to the rainfalls. Figure $7 \mathrm{~b}$ shows the daily streamflow level of Fucino channel, "a detail" of Fig. 7a. The two sites are very near each other. It shows how during April 1984 the sharp increase of 7 May cannot be imputed to the very small rainfalls on 6 May.
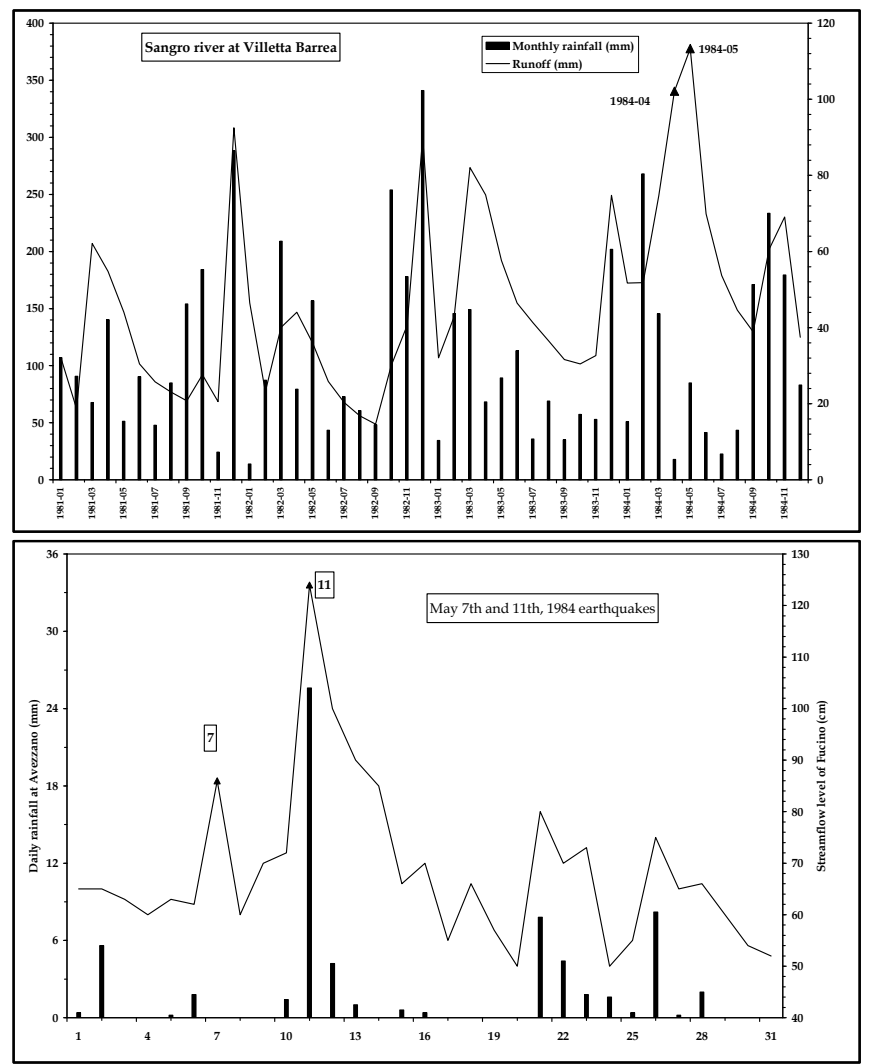

Fig. 7. Increase in the streamflow rate of the Sangro River at Villetta Barrea (a) and in daily streamflow level of Fucino channel (b). 


\section{Discussions and conclusions}

In the Southern Apennines we found that some earthquakes produced clear forerunner signals in various areas where geochemical and hydrological parameters were controlled.

These results seem to indicate that the hydrological phenomena are associated to the changes of the stress field, during and after an earthquake.

We analyzed the relations of primary tectonic effects with the local geomorphic and structural setting.

We have also applied for some category of secondary effects a statistical test to infer the presence of trends and a regression analysis based on least-squares method was performed. In particular, a simple bivariate scatter plot of two variables have been computed, specifically: macroseismic intensities versus epicentral or fault distances of hydrological anomalies. Figure 4 shows for the 1930 earthquake the trend macroseismic intensity-distance from the epicentre. Very similar trends have been found for the 1980 and 1984 earthquakes. Hydrological phenomena occurred throughout the macroseismic field, and were the most numerous among the induced effects. They include flow increase both in spring and well, turbid water and drying up of springs, and even creation of new springs. Some variations in chemical parameters of the waters were observed at different locations, both inside and outside the epicentral areas. The data relative to the hydrological variations' distribution versus the distance from the epicentre show that the high concentration of phenomena lie between $25-80 \mathrm{~km}$, about $20 \%$ are inside the epicentral area $(0-25 \mathrm{~km})$; few phenomena occurred at greater distances.

A dramatic increase in the springs' flow implies the deformation of major tectonic blocks, which influences deep aquifers. Examples are shown in figures 5d,e (Cassano Irpino springs) and figure $5 f$ (Sanità spring near Caposele) during the 23 November 1980 earthquake.

A remarkable aspect of these anomalies is that they were observed at distances of more than 200 kilometers from the earthquake epicentral area. This suggest that the impact of the Irpinia earthquake on the hydrogeologic structure of the Southern Apennines was more important, in terms of both total number of recorded anomalies and for their epicentral and fault distance.

Today there are no valid earthquake precursors, but many effects are invoked as good forerunners: geophysical changes $\left(\mathrm{v}_{\mathrm{p}} / \mathrm{v}_{\mathrm{s}}\right.$, telluric currents, electromagnetic effects), geochemical changes (chemical composition, $\mathrm{pH}$, water temperature, gases like $\mathrm{Rn}, \mathrm{CO}_{2}$ ) and hydrologic changes (piezometric levels, spring and stream flow).

Probably the simultaneous observation of all of these effects can constitute a sure forecasting. Many efforts and money are necessary for this purpose.

Taking into account that not always earthquakes are preceded by all of the above mentioned precursory phenomena, and that today's technology can provide probes for many geochemical and geophysical parameters at affordable cost, we maintain that a regional monitoring network can be installed in the Southern Apennines, in order to continuously control as many parameters as possible.

Hydrologic changes depend on both the structure of the aquifer and the strain that an earthquake induces on the area of the fault rupture.

Dobrovolsky et al. (1979) give a theoretical relation regarding earthquake magnitude, distance from the epicenter and volumetric strain. The "strain radius" $R_{s}$ of a circle centered on the epicenter, in which precursor deformations and other physical phenomena occur, is given by:

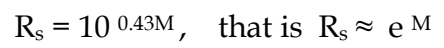


This exponential curve divides the areas where strain is lower than $10^{-8}$ and is greater than $10^{-8}$. For strain $=10^{-8}$ water level changes are only $1 \mathrm{~cm}$. The data of some earthquakes in Irpinia (table 1 in Onorati and Tranfaglia, 1994; tables 2, 4 and 6 in Porfido et al., 2007) are plotted in figure 8 and the strain radius is indicated.

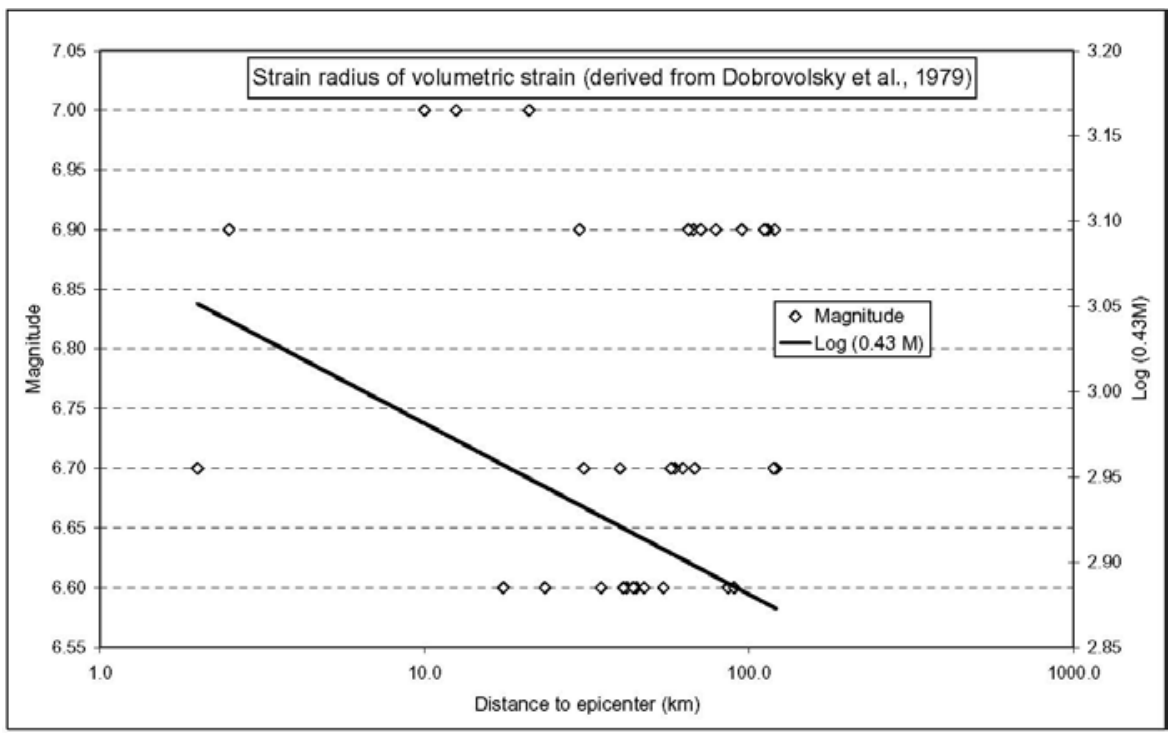

Fig. 8. (see text)

Montgomery and Manga (2003) suggest that the stream flow changes are attributable to liquefaction of valley bottom deposits. Papadopoulos and Lefkopoulos (1993) give an empirical maximum distance to the epicenter at which liquefaction can occur as a function of earthquake magnitude:

$$
\mathrm{M}=-0.44+3 \text { * } 10^{-8} \mathrm{D}_{\mathrm{e}}+0.98 \log \mathrm{D}_{\mathrm{e}},
$$

where $D_{e}$ is the distance to the epicenter in $\mathrm{cm}$. Figure 9 shows distance to epicentre for hydrological changes in rivers versus magnitude of Irpinia earthquakes in 1930, 1980 and 1984 (Porfido et al., 2007; Onorati and Tranfaglia, 1994). The liquefaction curve determined by the above relation is reported in figure 9. Because many hydrological changes are at distances greater than the liquefaction curve determined for valley bottom deposits, they can be caused by preseismic fracturing of carbonate aquifers in the Apennine Chain.

To define the normal hydrodynamic behaviour of an aquifer it is necessary to develop some stochastic models of the input-output type. Even the simplest stochastic model provides a lot of information on the aquifer's structure and on the connections between hydrologic variables. For this purpose an analysis of the correlation between rainfalls and water levels and flow rates has been carried out.

Four examples are reported in figures 10a-d, which shows the cross-correlograms obtained calculating the coefficients of cross-correlation for various lags. For the Pomigliano well (figure 10a), seasonal variations are evident and the coefficients of cross-correlation between the precipitations and the water table are statistically meaningful for delays until 30 months. This is in agreement with the fact that the Pomigliano well is on alluvial water table with 
superficial feeding due only to precipitations. For the Bucciano well (figure 10b), the crosscorrelogram increases of significance until to the maximum value of 150 lags (that is about 250 days). The minor components can be due to surface feeding, but the lag=150 component is certainly due to deep feeding from the carbonate aquifer of Taburno mount. In figure 10c and figure 10d similar trends appear: seasonal correlations are very clear for Sanità Spring, fed only by carbonate aquifers of Picentini mounts; while for Tasso river the minor components indicate surface feeding, but the great lag=90 component is due to the deep feeding from Marsicano mount.

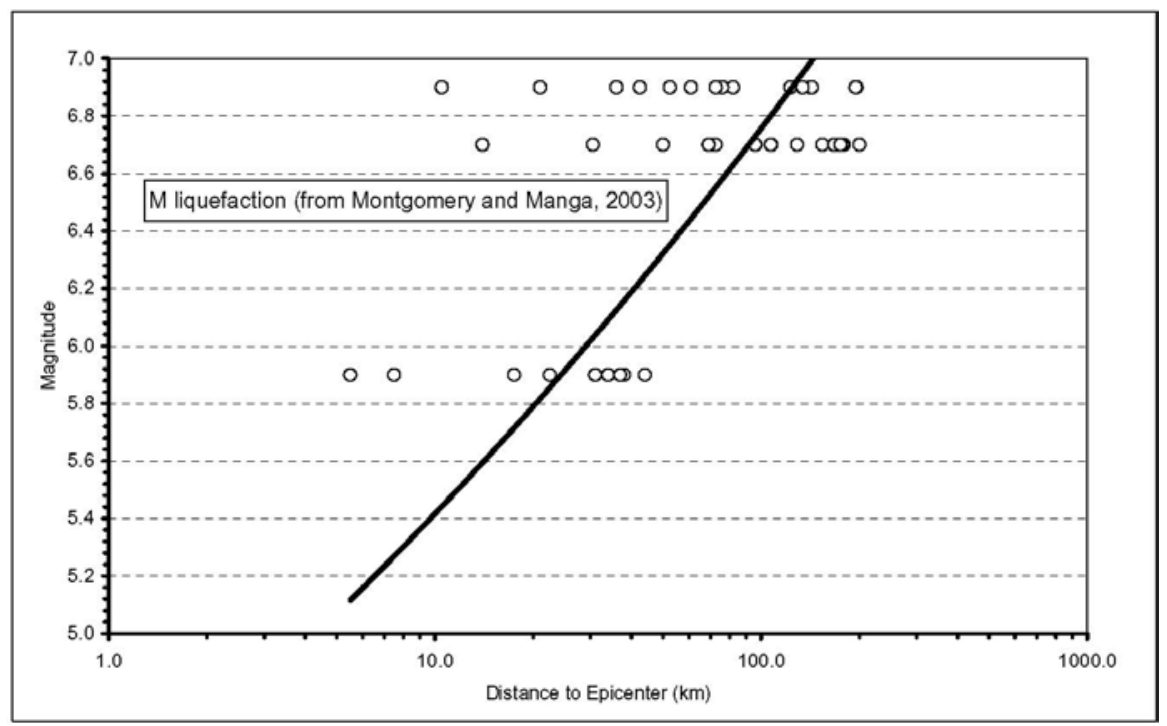

Fig. 9. (see text)

To conclude, the significant peaks can be attributed to the hydrodynamic behaviour of aquifers, and the delayed contribution from carbonate complex is evident. The delay of such peaks with respect to the start of the hydrological anomaly and/or its duration, can concur to define the space-time limits of the anomaly correlated with earthquake.

The study of the geochemical and hydrodynamic characteristics of aquifers is acknowledged to make a valid contribution to understanding the natural processes connected to earthquakes (King et al., 1981; King, 1985; Bredehoeft et al., 1987; Roeloffs et al., 1989; Kissin and Grinevsky, 1990; King et al., 1994; Quilty and Roeloffs, 1997; Ingebritsen and Sanford, 1999). Changes in the water-rock interaction are caused by the seismic stresses in the area where the tectonic deformation leads to the seismic event (Rojstaczer and Wolf, 1992, 1994; King and Muir-Wood, 1993; Quilty and Roeloffs, 1997; Roeloffs, 1998; Ingebritsen and Sanford, 1999; Manga, 2001).

Various mechanisms have been invoked to explain earthquake-related changes in water tables and in spring and stream discharges:

1. Large (as much as $20 \mathrm{~m}$ ), near-field (probably $<50 \mathrm{~km}$ from the epicenter) water level declines can sometimes be related to near-surface permeability enhancement due to ground motion (Rojstaczer and Wolf, 1992, 1994; Rojstaczer et al., 1995). These authors limit the validity of the relationship between seismic intensity and areas with water increases only to normal fault earthquakes. 

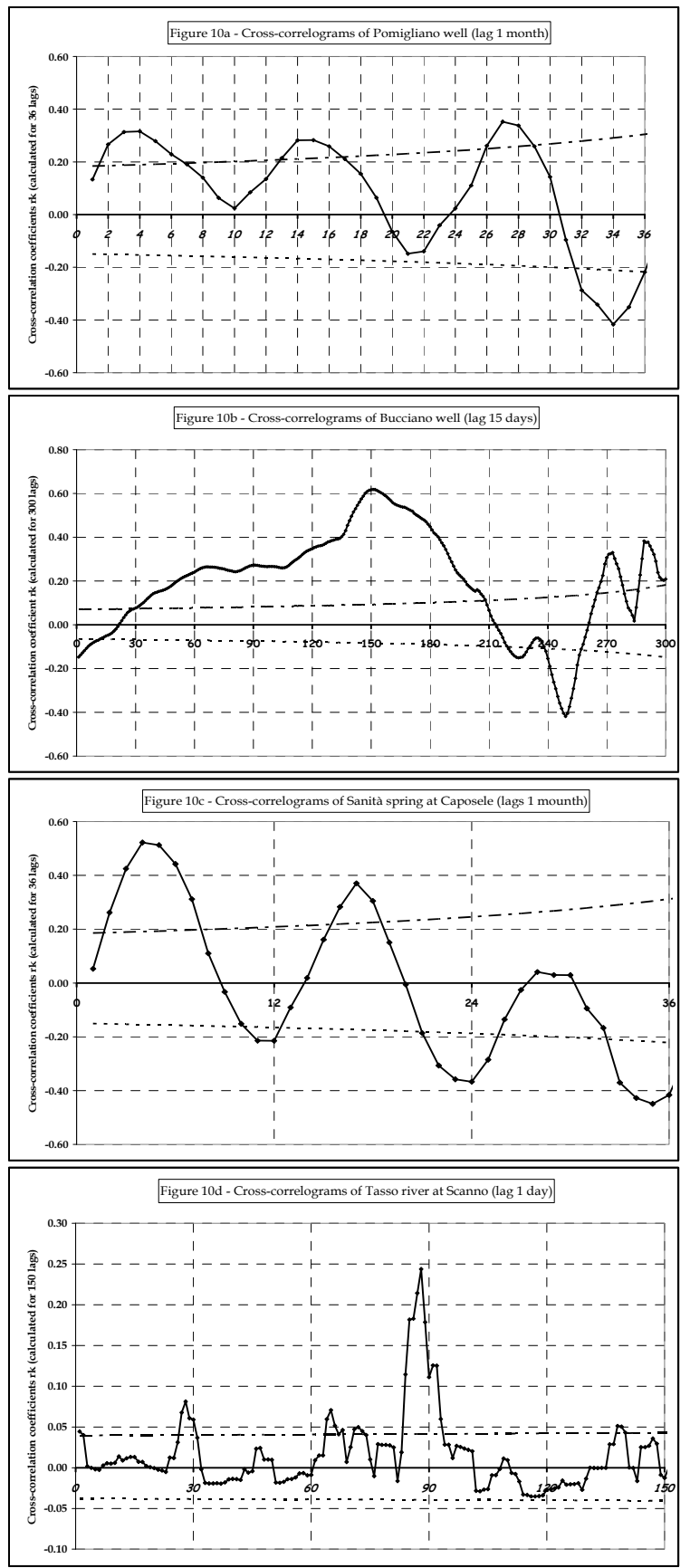

Fig. 10. Cross-correlograms of (a) Pomigliano (lag 1 month), (b) Bucciano wells (lag 15 days), Sanità spring at Caposele (lag 1 month) and Tasso river at Scanno (lag 1 day). 
2. King and Muir-Wood (1993) proposed a model of deformation in complex fault systems with different mechanisms and orientations. In the model, the coseismic dislocations during strong earthquakes produce a deformation of the crust which directly influences the surface aquifers. Furthermore, in the inter-seismic periods in areas undergoing crustal extension, there is an increase in pore volume, which is then filled by percolating fluids with a consequent decrease of levels in underground waters. After a normalfaulting earthquake, the stress release produces a decrease in pore volumes and hence an increase in water levels. This hydrological behaviour can be considered a precursor anomaly. In areas undergoing inter-seismic compression, the anomalous behaviour has the opposite sign.

3. Quilty and Roeloffs (1997) analysed co-seismic changes in water level in nine wells near Parkfield, California, produced by an earthquake on 20 December 1994 (M=4.7), in order to test the hypothesis that coseismic water level changes (which for nine wells ranged from -16 to $+34 \mathrm{~cm}$ ) are proportional to coseismic volumetric strain.

4. According to Cooper et al. (1965), most of the coseismic water level oscillations observed at larger distances are resonance phenomena caused by particular fracture patterns of the formations where wells are located, that act to amplify a very small crustal strain signal.

The negative anomalies found in this work can be considered "rebound anomalies", which are the most common precursor reported by many authors and are related to increases in porosity and permeability caused by fracturing that precedes an earthquake (Roeloffs, 1988; Igarashi et al., 1992).

The total excess discharge $\left(0.035 \mathrm{~km}^{3}\right)$ caused by the Irpinia 1930 earthquake $(\mathrm{Ms}=6.7)$ of 11 streams (table 3) is comparable with the excess discharge of about $0.01 \mathrm{~km}^{3}$ for the Loma Prieta earthquake (Mw=6.9) (Rojstaczer and Wolf, 1992, 1994).

\section{References}

Alfano, G.B. (1931). Il terremoto irpino del 23 luglio 1930, Osservatorio di Pompei 1931, 3-57.

Bredehoeft, J.D., Riley, F.S., and Roeloffs, E.A. (1987). Earthquakes and Groundwater, Earthquakes and Volcanoes, 19 (4), 142-146.

Briggs, R.O. (1994). Effects of the earthquakes on surface waters in Waddell Valley, in The Loma Prieta (California) Earthquake of Oct. 17, 1989 - Hydrologic disturbances, U.S.G.S. Prof. Paper 1551-E, 21-30.

Celentani Ungaro, P. (1931). Effetti del terremoto irpino del 23 luglio 1930 - VIII sulle opere dell'Acquedotto Pugliese, L'Ingegnere, V, September 1931.

Cinque, A., Patacca, E., Scandone, P., and Tozzi, M. (1991). Quaternary kinematic evolution of the Southern Apennines. Relationship between surface geological features and deep lithospheric structures, Annali di Geofisica, 36(2), 249-260.

Cooper, H.H., Bredehoeft, J.D., Papadopulos, I.S., and Bennet, R.R. (1965). The response of well-aquifer systems to seismic waves, J. Geophys. Res. 70, 3915-3926.

Curry, R.R., Emery, B.A, and Kidwell, T.G. (1994). Sources and magnitudes of increased streamflow in the Santa Cruz Mountains for the 1990 water year after the earthquake. In: The Loma Prieta (California) Earthquake of October 17, 1989 Hydrologic disturbances, U.S.G.S. Prof. Pap. 1551-E, 31-50.

Dobrovolsky I.P., Zubkov S.I., and Miachkin V.I. (1979). Estimation of the size of earthquake preparation zones, Pageoph, 117, 1025-1044. 
Doglioni, C., Harabaglia, P., Martinelli, G., Monelli, F., and Zito, G. (1996). A geodynamic model of the Southern Apennines accretionary prism, Terra Nova 8, 540-547.

Esposito, E., Pece, R., Porfido, S., and Tranfaglia, G. (2001). Hydrological anomalies precursory of earthquakes in Southern Apennines (Italy), Natural Hazards and Earth System Sciences 1, 137-144.

Esposito, E., Pece, R., Porfido, S., and Tranfaglia, G. (2009). Ground effects and hydrological changes in the Southern Apennines (Italy) in response to the 23 July 1930 earthquake $\left(\mathrm{M}_{\mathrm{s}}=6.7\right)$, Natural Hazards and Earth System Sciences 9, 539-550.

Freeman, J.R. (1930). The Italian Earthquake of July 23, 1930, Bull. Seismol. Soc. Amer. 20(4), 241-260.

Gasperini, P., Bernardini, F., Valensise, G., and Boschi, E. (1999). Defining seismogenic sources from historical earthquake felt report, Bull. Seismol. Soc. Amer. 89, 94-110.

Gordon F.R. (1970). Water level changes preceding the Meckering, Western Australia, earthquake of October 14, 1968, Bull. Seismol. Soc. Amer. 60(5), 1739-1740.

Hill, D.P., Pollitz, F., and Newhall, C. (2002). Earthquake-volcano interactions, Physics Today 11, 41-47.

Husen, S., Taylor, R., Smith, R. B., and Healser, H. (2004). Changes in geyser eruption behavior and remotely triggered seismicity in Yellowstone National Park produced by the 2002 M 7.9 Denali fault earthquake, Alaska, Geology 32 (6), 537-540.

Igarashi, G., Wakita, H., and Sato, T. (1992). Precursory and coseismic anomalies in well water levels observed for the February 2, 1992 Tokyo Bay earthquake, Geoph. Res. Letters 19(15), 1583-1586.

Ingebritsen, S.E., and Sanford, W.E. (1999). Groundwater in geologic processes, Cambridge University Press. Chapter 8, 215-245.

Italian Hydrographic Survey Annals (1926-1990). Annali Idrologici, Parte I e II, Published by Napoli, Pescara and Bari Hydrographic Departments.

Italiano, F., Martelli, M., Martinelli, G., and Nuccio, P.M. (2000). Geochemical evidence of melt intrusions along lithospheric faults of the Southern Apennines, Italy: geodynamic and seismogenic implications, Jour. Geoph. Res. 105(B6), 13569-13578.

King, C.Y., Evans, W.C., Presser, T., and Husk, R.H. (1981). Anomalous chemical changes in well waters and possible relation to earthquakes, Geophys. Res. Lett 8(5), 425-428.

King, C.Y. (1985). Earthquake hydrology and chemistry, Pure Appl. Geophys. 122, (2-4), 141142.

King G.C.P. and Muir-Wood R. (1993). Hydrological Signatures of Earthquake Strain. Jour. Geoph. Res., Vol. 98, B12, pp. 22035-22068.

King, C.Y., Basler, D., Presser, T.S., Evans, W.C., White, L.D., and Minissale, A. (1994). In search of earthquake-related hydrologic and chemical changes along Hayward fault, Applied Geochemistry 9, 83-91.

Kissin, I.G., and Grinevsky, A.O. (1990). Main features of hydrogeodynamic earthquake precursors, Tectonophysics 178, 277-286.

Majo, E. (1931). I fenomeni geofisici Flegrei susseguenti al terremoto irpino del 23 luglio 1930, Bollettino Società Naturalisti Napoli 43, 361-365.

Manga, M. (2001). Origin of postseismic streamflow changes inferred from baseflow recession and magnitude-distance relations, Geophys. Res. Lett. 28(10), 2133-2136.

Montgomery, D. R., and Manga, M. (2003). Streamflow and water well responses to earthquakes, Science 300, 2047-2049. 
Oddone, E. (1932). Studio sul terremoto avvenuto il 23 luglio 1930 nell'Irpinia, in: La meteorologia pratica, Ufficio Centrale di Meteorologia e Geofisica, 16-26, 77-84, 116-125, 171-176.

Onorati, G., and Tranfaglia, G. (1994). L'anomalia idrologica che ha preceduto i terremoti del maggio 1984 nel Parco Nazionale d'Abruzzo, in: Terremoti in Italia - Previsione e prevenzione dei danni, Accademia Nazionale dei Lincei, Rome, 285-293.

Pantosti, D., Schwartz, D. P., and Valensise, G. (1993). Paleoseismology Along the 1980 Surface Rupture of the Irpinia Fault: Implications for Earthquake Recurrence in the Southern Apennines, Italy, Jour. Geophys. Res. 98, 6561-6577.

Papadopoulos G.A., and Lefkopoulos G. (1993). Magnitude-distance relations for liquefaction in soil from earthquakes, Bull. Seismol. Soc. Amer. 83(3), 925-938.

Pece, R., Tranfaglia, G., and Avino, R. (1999). Geochemical monitoring integrated in a real time hydrological network, Il Nuovo Cimento 22 C(3-4), 483-490.

Porfido S., Esposito E., Guerrieri L., Vittori E., Tranfaglia G., Pece R. (2007). Seismically induced ground effects of the 1805, 1930 and 1980 earthquakes in the Southern Apennines, Italy, Ital. J. Geosci. (Boll. Soc. Geol. It.),126(2), 333-346.

Quilty, E.G. and Roeloffs, E.A. (1997). Water-level changes in response to the 20 December 1994 earthquake near Parkfield, California, Bull. Seismol. Soc. Amer. 87(2), 310-317.

Roeloffs, E.A., Schulz Burford, S., Riley, F.S., and Records, A.W. (1989). Hydrologic effects on water level changes associated with episodic fault creep near Parkfield, California, Jour. Geophys. Res. 94(B9),12387-12402.

Roeloffs, E.A. (1998). Persistent water level changes in a well near Parkfield, California, due to local and distant earthquakes, Jour. Geophys. Res 103(B1), 869-889.

Rojstaczer, S.A., and Wolf, S. (1992). Permeability changes associated with large earthquakes: An example from Loma Prieta, California, 10/17/89. Geology 20, 211214.

Rojstaczer, S.A., and Wolf, S. (1994). Hydrologic changes associated with the earthquake in The San Lorenzo and Pescadero drainage basins. In: The Loma Prieta (California) earthquake of October 17, 1989 - Hydrologic disturbances, U.S.G.S. Prof. Paper 1551-E, 51-64.

Rojstaczer S.A., Wolf, S., and Michel, R. (1995). Permeability enhancement in the shallow crust as a cause of earthquake-induced hydrological changes, Nature 373, 237-239.

Schuster, R.L., and Murphy, W. (1996). Structural damage, ground failure, and hydrologic effects of the magnitude $\left(\mathrm{M}_{\mathrm{w}}\right) 5.9$ Draney Peak, Idaho, earthquake of February 3, 1994, Seismological Research Letters 67 (3), 20-29.

Sorey, M.L., and Clark, M.D. (1981). Changes in the discharge characteristics of thermal springs and fumaroles in the Long Valley caldera, California, resulting from earthquakes on May 25-27, 1980, U.S.G.S. Open File Rep. 81-203.

Sugisaki, R., and Sugiura, T. (1986). Gas anomalies at three mineral springs and a fumarole before an Inland earthquake, Central Japan, Jour. Geophys. Res. 91(B12), 12996-12304.

Thorson, R.M. (2001). Remote aquifer response to the 18 November 1755 Cape Anne earthquake, Seismological Research Letters, 72 (3), 401-403.

Spadea, M.C., Vecchi, M., Gardellini, P., Del Mese, S. (1985). The Irpinia earthquake of July 23, 1930, in: Atlas of isoseismal maps of Italian earthquakes, Consiglio Nazionale delle Ricerche ed. 
Wakita, H., Nakamura, Y., and Sano, Y. (1985). Groundwater radon variations reflecting changes in regional stress fields, Earthquake Prediction Research 3, 545-557.

Westaway R., Gawthorpe R., Tozzi M. (1989). Seismological and field observation of the 1984 Lazio-Abruzzo earthquakes: implications for the active tectonics of Italy. Geophysical Journal, 98, 489-514.

Westaway, R. (1992). Seismic moment summation for historical earthquakes in Italy: Tectonic implications, Jour. Geophys. Res. 97(B11), 15437-15464, Correction (1993), Jour. Geophys. Res. 98(B3), 4539.

Westaway, R. (1993). Quaternary Uplift of Southern Italy, Jour. Geophys. Res. 98(B12), 2174121772.

Whitehead, R.L., Harper, R.W., and Sisco, H.G. (1984). Hydrologic changes associated with the October 28, 1983, Idaho earthquake, Pure Appl. Geophys. 122, 280-293. 


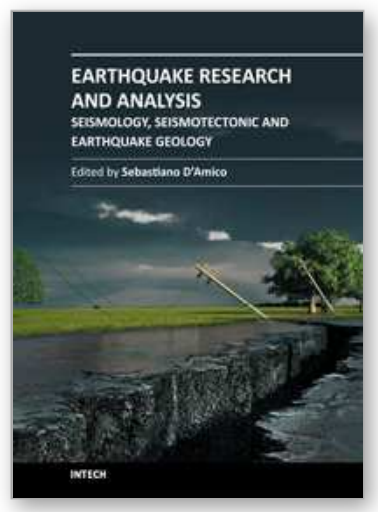

\section{Earthquake Research and Analysis - Seismology, Seismotectonic and Earthquake Geology}

Edited by Dr Sebastiano D'Amico

ISBN 978-953-307-991-2

Hard cover, 370 pages

Publisher InTech

Published online 08, February, 2012

Published in print edition February, 2012

This book is devoted to different aspects of earthquake research. Depending on their magnitude and the placement of the hypocenter, earthquakes have the potential to be very destructive. Given that they can cause significant losses and deaths, it is really important to understand the process and the physics of this phenomenon. This book does not focus on a unique problem in earthquake processes, but spans studies on historical earthquakes and seismology in different tectonic environments, to more applied studies on earthquake geology.

\section{How to reference}

In order to correctly reference this scholarly work, feel free to copy and paste the following:

Raimondo Pece and Giuseppe Tranfaglia (2012). Hydrological and Geochemical Changes Related to Earthquakes - Examples: Three Great Earthquakes of the XX Century in the Southern Apennines (Italy), Earthquake Research and Analysis - Seismology, Seismotectonic and Earthquake Geology, Dr Sebastiano D'Amico (Ed.), ISBN: 978-953-307-991-2, InTech, Available from:

http://www.intechopen.com/books/earthquake-research-and-analysis-seismology-seismotectonic-andearthquake-geology/hydrological-and-geochemical-changes-related-to-earthquakes-examples-three-greatearthquakes-of-the-

\section{INTECH}

open science | open minds

\author{
InTech Europe \\ University Campus STeP Ri \\ Slavka Krautzeka 83/A \\ 51000 Rijeka, Croatia \\ Phone: +385 (51) 770447 \\ Fax: +385 (51) 686166 \\ www.intechopen.com
}

\author{
InTech China \\ Unit 405, Office Block, Hotel Equatorial Shanghai \\ No.65, Yan An Road (West), Shanghai, 200040, China \\ 中国上海市延安西路65号上海国际贵都大饭店办公楼 405 单元 \\ Phone: +86-21-62489820 \\ Fax: +86-21-62489821
}


(C) 2012 The Author(s). Licensee IntechOpen. This is an open access article distributed under the terms of the Creative Commons Attribution 3.0 License, which permits unrestricted use, distribution, and reproduction in any medium, provided the original work is properly cited. 